\title{
IMPLEMENTASI TALENT MANAGEMENT DAN MOTIVASI KERJA IMPLIKASINYA PADA KINERJA PEGAWAI DIREKTORAT
}

\author{
Oleh: \\ Irni Diniati* , Aan Komariah, Dedy Achmad Kurniady \\ Universitas Pendidikan Indonesia \\ (email : irni.diniati@student.upi.edu*, aan_komariah@upi.edu, dedy achmad@upi.edu)
}

\begin{abstract}
ABSTRAK
Penelitian ini bertujuan untuk menganalisis pengaruh Talent Management dan Motivasi Kerja terhadap Kinerja pegawai Direktorat PGTK PAUD dan Dikmas Kemdikbud dengan metode kuantitatif menggunakan regresi linier berganda. Hasil penelitian menunjukkan pada tahun 2018 ketiga variabel kinerja, talent management, dan motivasi kerja pegawai berada pada kategori "tinggi". Berdasarkan pengolahan data, talent management berpengaruh secara positif signifikan terhadap kinerja pegawai. Begitu pula halnya dengan motivasi kerja yang juga berpengaruh secara positif signifikan terhadap kinerja pegawai. Apabila kedua variabel independen ini digabungkan maka didapatkan hasil bahwa talent management dan motivasi kerja secara bersama-sama berpengaruh sebesar $46,4 \%$ terhadap kinerja pegawai, sementara sisanya sebesar 53,6\% dipengaruhi oleh faktor lain. Namun dalam uji parsialnya (uji t), meskipun kedua variabel tersebut berpengaruh terhadap kinerja pegawai, dapat disimpulkan bahwa khusus variabel talent management dianggap tidak berpengaruh secara signifikan.
\end{abstract}

Kata Kunci: Kinerja Pegawai, Motivasi Kerja, Talent Management

\section{ABSTRACT}

This study aims to analyze the variables of Talent Management and Work Motivation on the Performance of Direktorat PGTK PAUD dan Dikmas Kemdikbud with quantitative method using multiple linear regression. The results show in 2018 is that performance, talent management, and work motivation variables are in the "high" category. Based on data processing, talent management has a significant positive effect on employee performance. Similarly, the work motivation also has a significant effect on employee performance. If the two variables are combined, the result shows that talent management and work motivation are simultaneously affecting on performance in amount of $46.4 \%$, while the remaining $53.6 \%$ are affected by other factors. But in the partial test ( $t$ test), eventhough both independent variables are affecting the dependent variable simultaneously, the talent management variable are considered ineffectively significant.

Keywords: Employee Performance, Talent Management, Work Motivation

\section{PENDAHULUAN}

Salah satu faktor yang mempengaruhi kualitas SDM yang Smart, Speed, dan Solid ini adalah faktor individu yang di dalamnya termasuk talent sebagai kemampuan yang dimiliki setiap individu. Organisasi yang memiliki SDM dengan talent yang sesuai dengan kebutuhan organisasi akan membuat organisasi tersebut lebih unggul dan berkualitas internasional. Dengan semakin besarnya kesadaran organisasi akan talent tersebut, maka mereka akan bersaing untuk mendapatkan pegawai bertalenta tinggi, baik dengan cara menjaring dari luar ataupun pelatihan dan kaderisasi.

Proses mengelola sumber daya manusia mulai dari menjaring (merekrut) hingga mempertahankan tenaga kerja ini merupakan bagian dari talent management. Beberapa komponen-komponen kunci yang mencirikan diterapkannya proses talent management dalam suatu organisasi adalah perekrutan dan seleksi, orientasi, manajemen kinerja, pengakuan dan retensi, pendidikan dan pelatihan, dan pengembangan kaderisasi (Pella \& Inayati, 2011, hal. 84-85). Talent management intinya adalah mencari orang yang tepat dengan keterampilan yang tepat untuk posisi yang tepat pula (Cappelli, 2009, hal. 1). Talent management sangat erat kaitannya dengan Human Capital Management (HCM) dan berbeda dengan Human Resource Management. Pada Human Resource 
Management, manusia dianggap sebagai sumber daya yang akan habis dikonsumsi sehingga seluruh biaya yang dikeluarkan untuk pengelolaan sumber daya manusia akan diperlakukan sebagai expense. Sementara Human Capital Management memiliki premis bahwa sumber daya manusia dianggap sebagai modal utama di antara semua aset yang dimiliki organisasi. Tenaga kerja dinilai sebagai aset dinamis yang nilainya dapat terus-menerus naik. Sehingga berapapun biaya yang dikeluarkan untuk pengelolaannya dianggap investasi.

Kendati demikian, bakat yang dimiliki seorang talent tak muncul begitu saja. Meskipun seseorang sudah memiliki bakat sejak awal, namun terkadang bakat tersebut masih tersembunyi dan butuh suatu dorongan untuk dapat muncul dan diperlihatkan. Bakat seseorang bisa saja kurang berkembang atau tidak menonjol apabila tak ada motivasi atau dorongan dari dalam maupun luar dirinya untuk dikembangkan.

Menurut Nawawi (1997, hal. 351), motivasi diartikan sebagai kondisi yang mendorong atau menjadi sebab seseorang melakukan suatu pekerjaan, yang berlangsung secara sadar. Seiring dengan hal tersebut, motivasi kerja juga didefinisikan sebagai kondisi yang berpengaruh membangkitkan, mengarahkan, dan memelihara perilaku yang berhubungan dengan lingkungan kerja (Mangkunegara, 2016, hal. 94). Sehingga dengan motivasi tertentu, seseorang akan dapat menghasilkan suatu kinerja yang berpadu dengan unsur kemampuan atau ability (Adriyanto, 2014, hal. 23).

Dalam Teori Hierarki Kebutuhan Abraham H. Maslow seperti dijelaskan Sayekti dkk (2011, hal. 71), dalam diri manusia bersemayam lima jenjang kebutuhan di antaranya kebutuhan psikologis, kebutuhan akan keamanan, kebutuhan sosial, kebutuhan akan penghargaan, dan kebutuhan akan aktualisasi diri. Kebutuhan untuk mengaktualisasi diri berarti kebutuhan untuk menggunakan kemampuan, skill, dan potensi (Mangkunegara, 2016, hal. 95). Sehingga mengasah talent juga dapat dikategorikan sebagai menggunakan kemampuan, skill, dan potensi yang adalah termasuk salah satu perwujudan dari aktualisasi diri tersebut.

Pada teori kebutuhan lainnya seperti dijelaskan Siagian (2009, hal. 108), David McClelland menggolongkan kebutuhan manusia menjadi tiga jenis di antaranya kebutuhan akan keberhasilan (need for achievement), kebutuhan akan kekuasaan (need for power), dan kebutuhan akan afiliasi (need for affiliation). Need of power atau kebutuhan akan kekuasaan dapat dikaitkan erat dengan talent management, sesuai dengan karakteristik dan tujuannya yaitu mengidentifikasi sistemik posisi kunci untuk kemudian diisi oleh kader yang kompeten. Di mana kader kompeten inilah yang nantinya akan ditempatkan untuk mengisi posisi-posisi strategis pemimpin masa depan di organisasi tersebut, yang setidaknya sudah tentu pada akhirnya akan memasuki masa purnabakti.

Direktorat PGTK PAUD dan Dikmas Kemdikbud merupakan satuan kerja unit eselon II yang berada di bawah naungan Kementerian Pendidikan dan Kebudayaan Republik Indonesia. Lembaga ini menangani seluruh permasalahan tentang pembinaan guru dan tenaga kependidikan (non guru) pada lembaga Pendidikan Anak Usia Dini (PAUD) serta lembaga pendidikan non formal dan informal lainnya. Hal ini menjadikan Direktorat PGTK PAUD dan Dikmas Kemdikbud sebagai salah satu lembaga yang berperan sangat penting dan cukup disorot oleh masyarakat terutama dari kalangan guru dan tenaga kependidikan lembaga nonformal dan informal yang tersebar di seluruh penjuru Indonesia. 
Guna menjaga optimalisasi kinerja Direktorat PGTK PAUD dan Dikmas Kemdikbud, diperlukan upaya-upaya penanggulangan agar tidak berdampak lebih jauh. Maka dari itu, dilakukanlah penelitian yang bertujuan untuk mendapatkan gambaran empirik mengenai pengaruh talent management dan motivasi kerja terhadap kinerja pegawai Direktorat PGTK PAUD dan Dikmas Kemdikbud ini.

\section{METODE PENELITIAN}

Penelitian ini menggunakan metode penelitian survey dengan pendekatan kuantitatif. Dari sisi eksplanasi, penelitian ini berjenis deskriptif yang ditujukan untuk memecahkan masalah yang terjadi pada masa sekarang. Sementara desain penelitian untuk pengukuran pengaruh variabel bebas terhadap variabel terikat dalam penelitian ini digambarkan sebagai berikut:

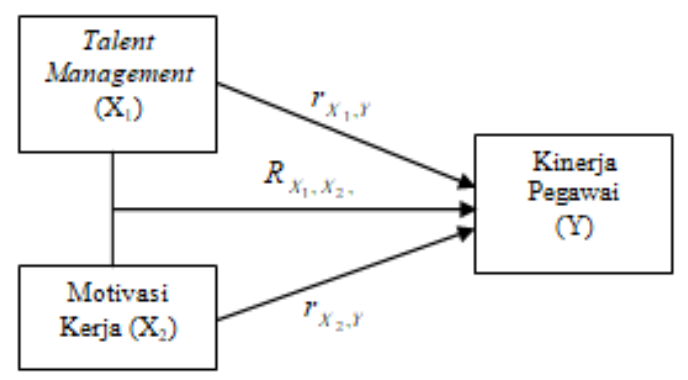

Gambar 1. Desain Penelitian

Adapun lokasi penelitian mengambil tempat di Direktorat PGTK PAUD dan Dikmas Kemdikbud yang berada di bawah dan bertanggung jawab secara langsung kepada Direktur Jenderal Guru dan Tenaga Kependidikan
Kementerian Pendidikan dan Kebudayaan. Target populasi dalam penelitian ini adalah staf yang sedang bekerja aktif di lingkungan Direktorat PGTK PAUD dan Dikmas Kemdikbud. Dari sebanyak 84 orang staf yang ada pada Direktorat PGTK PAUD dan Dikmas Kemdikbud, sebanyak satu orang staf sedang menjalani tugas belajar dan dua orang sisanya sedang diperbantukan di tempat lain. Sehingga jumlah populasi dalam penelitian ini adalah sebanyak 81 orang staf yang aktif bekerja di Direktorat PGTK PAUD dan Dikmas Kemdikbud.

Dalam pengambilan sampel, Sugiyono (2016, hal. 92-94) menjelaskan bahwa apabila populasi mempunyai anggota/unsur yang tidak homogen dan berstrata secara kurang proporsional, maka teknik Probability Sampling yang digunakan adalah Disproportionate Stratified Random Sampling. Dan sebagai salah satu penelitian sosial, penelitian ini mengambil presisi sebesar 5\% dengan tingkat kepercayaan 95\%, Sehingga jumlah sampel yang ditentukan dalam penelitian ini adalah 68 orang.

\section{HASIL PENELITIAN}

\section{Analisis Deskriptif Variabel Penelitian}

Pengolahan data dalam penelitian ini dilakukan dengan tahapan-tahapan yang diambil dari pemberian bobot nilai untuk setiap alternatif jawaban responden, perhitungan frekuensi, dan rata-rata untuk setiap item pada masing-masing kolom. Berikut adalah tabel daftar untuk konsultasi hasil perhitungan dengan WMS (Weighted Means Score) yang kemudian menjadi pedoman dalam menentukan gambaran umum setiap variabel. Kriteria penafsiran dibuat dalam lima kategori, yaitu:

Tabel 1

Kriteria Penafsiran Perhitungan WMS

\begin{tabular}{ccc}
\hline $\begin{array}{c}\text { Rentang } \\
\text { Skor }\end{array}$ & Pilihan Jawaban & Kriteria \\
\hline $4,21-5,00$ & Sangat setuju (SS) & Sangat tinggi \\
$3,41-4,20$ & Setuju (S) & Tinggi \\
\hline
\end{tabular}




\begin{tabular}{|c|c|c|}
\hline $2,61-3,40$ & Ragu-ragu (RR) & Sedang \\
\hline $1,81-2,60$ & $\begin{array}{l}\text { Tidak Setujua } \\
\text { (TS) }\end{array}$ & Rendah \\
\hline $1,00-1,80$ & $\begin{array}{l}\text { Sangat tidak } \\
\text { setuju (STS) }\end{array}$ & $\begin{array}{l}\text { Sangat } \\
\text { rendah }\end{array}$ \\
\hline
\end{tabular}

Sumber: (Khoerudin, 2017)

Dengan menggunakan teknik WMS maka terlihat kecenderungan penilaian responden berdasarkan kriteria penafsiran WMS pada pernyataan yang tertuang dalam instrumen penelitian berkenaan dengan kinerja pegawai, talent management, dan motivasi kerja pegawai di lingkungan Direktorat PGTK PAUD dan Dikmas Kemdikbud, sebagai berikut:

Tabel 2.

Skor Rata-Rata Variabel Penelitian

\begin{tabular}{|c|c|c|}
\hline Variabel & $\begin{array}{l}\text { Rata- } \\
\text { Rata }\end{array}$ & $\begin{array}{c}\text { Kategori } \\
\text { WMS }\end{array}$ \\
\hline \multicolumn{3}{|l|}{ Kinerja } \\
\hline Kualitas & 4,41 & Sangat Tinggi \\
\hline Kuantitas & 3,86 & Tinggi \\
\hline Timelines & 4,29 & Sangat Tinggi \\
\hline Efektifitas & 4,06 & Tinggi \\
\hline Kesanggupan & 4,21 & Sangat Tinggi \\
\hline \multicolumn{3}{|l|}{ Talent Management } \\
\hline Mengidentifikasi & 3,81 & Tinggi \\
\hline $\begin{array}{l}\text { Merekrut dan } \\
\text { Menyeleksi }\end{array}$ & 3,43 & Tinggi \\
\hline Mengembangkan & 3,58 & Tinggi \\
\hline Mempertahankan & 3,84 & Tinggi \\
\hline \multicolumn{3}{|l|}{ Motivasi Kerja } \\
\hline Prestasi/Capaian & 4,42 & Sangat Tinggi \\
\hline Pengembangan Diri & 4,25 & Sangat Tinggi \\
\hline Tanggung Jawab & 3,72 & Tinggi \\
\hline Kemandirian & 3,99 & Tinggi \\
\hline
\end{tabular}

\section{Hasil Analisis Regresi Linier Berganda}

Hasil perhitungan koefisien regresi berganda dengan menggunakan program IBM SPSS Versi 22 diperoleh persamaan model regresi yaitu: $\hat{Y}=36,494+0,087 X_{1}+0,465 X_{2}$.

\section{Koefisien Determinasi $\left(\mathrm{R}^{2}\right)$}

Berdasarkan hasil perhitungan statistik diperoleh hasil adjusted $R^{2}$ sebesar 0,464 . Sehingga dapat disimpulkan bahwa Talent Management $\left(\mathrm{X}_{1}\right)$ dan Motivasi Kerja $\left(\mathrm{X}_{2}\right)$ berpengaruh sebesar 46,4\% terhadap Kinerja Pegawai (Y). Sedangkan sisanya sebesar $53,6 \%$ dipengaruhi oleh variabel lain yang tidak dibahas dalam penelitian ini.

\section{Hasil Uji F}

Berdasarkan hasil perhitungan statistik uji F, diperoleh nilai Fhitung $>$ Ftabel $(28,114>3,14)$ dan nilai Sig $0,000<0,05$. Sehingga dapat disimpulkan bahwa Talent Management $\left(\mathrm{X}_{1}\right)$ dan Motivasi Kerja $\left(\mathrm{X}_{2}\right)$ berpengaruh signifikan secara bersama-sama terhadap Kinerja Pegawai (Y).

\section{Hasil Uji Parsial (Uji t)}

Berdasarkan hasil perhitungan statistik uji parsial diperoleh hasil sebagai berikut:

1. Talent Management $\left(\mathrm{X}_{1}\right)$ dengan variabel Kinerja Pegawai $(\mathrm{Y})$ menunjukkan nilai Sig $0,116>0,05$. Sehingga dapat disimpulkan bahwa Talent Management $\left(\mathrm{X}_{1}\right)$ berpengaruh tidak signifikan secara parsial terhadap Kinerja Pegawai (Y).

2. Motivasi Kerja $\left(\mathrm{X}_{2}\right)$ dengan variabel Kinerja Pegawai (Y) menunjukkan nilai Sig $0,000<$ 0,05 . Sehingga dapat disimpulkan bahwa Motivasi Kerja $\left(\mathrm{X}_{2}\right)$ berpengaruh signifikan secara parsial terhadap Kinerja Pegawai (Y).

\section{PEMBAHASAN}

\section{Kinerja Pegawai Direktorat}

Berdasarkan hasil pengolahan dan analisis data penelitian melalui penyebaran angket yang telah dilakukan terhadap 68 pegawai, tingkat gambaran kinerja di lingkungan Direktorat PGTK
PAUD dan Dikmas Kemdikbud memperoleh nilai rata-rata sebesar 4,17 atau tergolong dalam kategori “tinggi”. Hal ini menunjukkan bahwa ratarata kinerja pegawai di lingkungan Direktorat PGTK PAUD dan Dikmas sudah dapat dikatakan 
baik. Dimensi pertama adalah kualitas dengan ratarata skor 4,41 dan termasuk dalam kategori "sangat tinggi”. Dimensi kedua adalah kuantitas dengan rata-rata skor 3,86 dan termasuk dalam kategori "tinggi". Dimensi ketiga adalah timelines dengan rata-rata skor 4,29 dan termasuk dalam kategori "sangat tinggi". Dimensi keempat adalah efektifitas dengan rata-rata skor 4,06 dan termasuk dalam kategori "tinggi. Dan dimensi terakhir adalah kesanggupan dengan rata-rata skor 4,21 dan termasuk dalam kategori "sangat tinggi". Dari lima dimensi yang diukur dari variabel kinerja pegawai, dimensi tertinggi adalah kualitas dengan skor ratarata 4,41. Sedangkan dimensi terendah adalah kuantitas dengan skor rata-rata 3,86.

Terlepas dari penilaian kinerja dalam perspektif lingkungan Aparatur Sipil Negara/Pegawai Negeri Sipil, sudah menjadi kesadaran secara pribadi bahwa melaksanakan pekerjaan bukan hanya sekadar menjadi suatu kebiasaan dan rutinitas saja, namun juga tentang memperhatikan kualitas, kecepatan dan kesanggupan. Kualitas hasil pekerjaan sangat mempengaruhi produktivitas individu dan organisasi. Sementara kuantitas dan efektifitas dalam bekerja merupakan faktor pendukung untuk meningkatkan kemampuan, keterampilan, dan pengalaman untuk pribadi maupun organisasi.

\section{Talent Management}

Gambaran talent management di lingkungan Direktorat PGTK PAUD dan Dikmas Kemdikbud memperlihatkan nilai rata-rata sebesar 3,66 atau tergolong dalam kategori "tinggi”. Hal ini menunjukkan bahwa pengaplikasian talent management di lingkungan Direktorat PGTK PAUD dan Dikmas sudah dapat dikatakan baik.

Dimensi pertama adalah mengidentifikasi dengan rata-rata skor 3,81 dan termasuk dalam kategori "tinggi". Dimensi kedua adalah merekrut menyeleksi dengan rata-rata skor 3,43 dan termasuk dalam kategori “tinggi”. Dimensi ketiga adalah mengembangkan dengan rata-rata skor 3,58 dan termasuk dalam kategori "tinggi". Dimensi keempat sekaligus terakhir adalah mempertahankan atau retensi dengan rata-rata skor 3,84 dan juga termasuk dalam kategori "tinggi. Dari empat dimensi yang diukur dari variabel talent management, dimensi tertinggi adalah mempertahankan dengan skor rata-rata 3,84. Sedangkan dimensi terendah adalah merekrut dan menyeleksi dengan skor rata-rata 3,43.

Dimensi mempertahankan cenderung memiliki skor tertinggi dikarenakan aturan pemerintah terkait lembaga pemerintah pada umumnya dan Direktorat PGTK PAUD dan Dikmas Kemdikbud khususnya menjamin para staf dan pensiunan pegawai negeri sipil untuk mendapatkan kompensasi materiil dan non materiil yang dapat menunjang kehidupan mereka dan keluarganya. Kelayakan kompensasi berupa gaji, tunjangan kinerja, jaminan kesehatan, jenjang karier, maupun tunjangan pensiun menghasilkan komitmen dan dedikasi pegawai terhadap organisasi, khususnya Direktorat PGTK PAUD dan Dikmas Kemdikbud. Hasil penelitian ini konsisten dengan hasil-hasil penelitian sebelumnya yang membuktikan bahwa pegawai akan merasa dihargai oleh organisasi jika mereka mendapatkan kompensasi yang layak. Pegawai akan termotivasi dan akan bekerja lebih baik untuk organisasi. Secara tidak langsung, pegawai cenderung akan bertahan di dalam organisasi tersebut (Astuti, 2014, hal. 212).

Sementara dimensi merekrut dan menyeleksi memiliki kecenderungan skor terendah dikarenakan adanya ketidakseimbangan antara kebutuhan dengan ketersediaan pegawai yang sesuai dengan talenta yang dibutuhkan organisasi. 
Keakuratan dalam penghitungan dan analisis beban kerja suatu jabatan serta prediksi dan proyeksi jumlah pegawai yang tersedia hingga beberapa tahun ke depan adalah beberapa faktor yang menentukan keseimbangan keadaan sumber daya manusia suatu organisasi. Penghitungan dan analisis beban kerja yang tidak tepat dan eligible akan memunculkan suatu kesenjangan, terlebih dengan adanya kemungkinan besar bahwa organisasi akan menghadapi permasalahan dan beban kerja yang semakin kompleks lagi di masa yang akan datang. Seiring dengan pendapat Devi Isna Hayati (2014, hal. 5) yang menyebutkan bahwa perencanaan dan kebutuhan masa depan sangat penting karena kemungkinan permasalahan yang dihadapi organisasi akan semakin kompleks, oleh karena itu diperlukan perumusan seperti jumlah pegawai yang diperlukan, kualifikasi, dan jangka waktu kebutuhan tersebut.

\section{Motivasi Kerja Pegawai}

Gambaran motivasi kerja di lingkungan Direktorat PGTK PAUD dan Dikmas Kemdikbud memperlihatkan nilai rata-rata sebesar 4,09 atau tergolong dalam kategori "tinggi". Hal ini menunjukkan bahwa tingkat motivasi kerja di lingkungan Direktorat PGTK PAUD dan Dikmas sudah dapat dikatakan baik.

Dimensi variabel motivasi kerja yang pertama adalah prestasi/capaian dengan rata-rata skor 4,42 dan termasuk dalam kategori "sangat tinggi”. Dimensi kedua adalah pengembangan diri dengan rata-rata skor 4,25 dan termasuk dalam kategori "sangat tinggi”. Dimensi ketiga adalah tanggung jawab dengan rata-rata skor 3,72 dan termasuk dalam kategori "tinggi". Dimensi keempat sekaligus terakhir adalah kemandirian dengan rata-rata skor 3,99 dan juga termasuk dalam kategori "tinggi. Dari empat dimensi yang diukur dari variabel talent management, dimensi tertinggi adalah prestasi/capaian dengan skor ratarata 4,42. Sedangkan dimensi terendah adalah tanggung jawab dengan skor rata-rata 3,72.

Dimensi prestasi/capaian dapat dikategorikan sebagai motivasi intrinsik. Ini berarti pendorong kerja pegawai cenderung bersumber dari dalam diri pegawai itu sendiri. Unsur-unsur pendorong dari dalam diri pegawai meliputi dorongan untuk bekerja, kemajuan dalam karier, pengakuan yang diperoleh, tanggung jawab dalam pekerjaan, minat terhadap tugas, dan dorongan untuk berprestasi (Rahmawati, 2015, hal. 115). Berdasarkan hal tersebut, maka penelitian yang dilakukan terhadap pegawai di lingkungan Direktorat PGTK PAUD dan Dikmas Kemdikbud ini menunjukkan bahwa motivasi intrinsik yang ada pada responden cenderung kepada dorongan untuk berprestasi.

Motivasi intrinsik dapat berupa kesadaran mengenai pentingnya atau manfaat/makna pekerjaan yang dilaksanakannya. Motivasi intrinsik adalah motivasi yang disebabkan oleh faktor internal di dalam diri individu dan inheren dalam tugas yang dilakukannya (Eriany, Hernawati, \& Goeritno, 2014, hal. 119). Pegawai yang termotivasi secara intrinsik mungkin terlibat dalam pekerjaan yang memberinya kepuasan, mengembangkan kemampuan, atau secara etika dan moral dirasa benar untuk dilakukan. Pegawai dengan motivasi intrinsik yang tinggi menjadi sangat terfokus dan hanyut dalam pekerjaannya hingga terkadang tidak memperdulikan waktu hingga mengabaikan aktivitas lainnya.

Di lain pihak, dimensi tanggung jawab berhubungan dengan penghasilan untuk memenuhi kebutuhan hidup keluarga, sehingga dapat dikategorikan sebagai motivasi ekstrinsik atau dari luar diri individu pegawai itu sendiri. Hal ini sesuai dengan pernyataan Nawawi seperti dikutip 
Permana (Jannah \& Endratno, 2017, hal. 44), motivasi ekstrinsik adalah pendorong kerja yang bersumber dari luar diri pekerja sebagai individu, berupa suatu kondisi yang mengharuskan melaksanakan pekerjaan secara maksimal.

Jannah dan Endratno (2017, hal. 44) juga menambahkan, beberapa indikator yang digunakan dalam mengukur motivasi ekstrinsik di antaranya gaji yang sesuai harapan, tunjangan jabatan berupa financial sudah memadai, jaminan sosial yang memadai, pemberian bonus kerja yang memadai, dan tunjangan hari raya yang sesuai harapan. Penelitian yang dilakukan pada pegawai di lingkungan Direktorat PGTK PAUD dan Dikmas Kemdikbud menunjukkan bahwa motivasi ekstrinsik memperlihatkan kecenderungan yang tidak setinggi motivasi intrinsik. Hal ini dikarenakan jika dinilai dari tingkat kepentingan atau prioritas, meskipun kompensasi yang diberikan organisasi kepada pegawai sudah dinilai cukup untuk memenuhi kebutuhan primer, namun kebutuhan tersier atau kebutuhan lux pegawai dinilai masih belum begitu tercukupi. Meskipun demikian, belum tercukupinya kebutuhan tersier ini pulalah yang memotivasi pegawai untuk terus bekerja lebih keras lagi.

\section{Talent Management terhadap Kinerja Pegawai}

Gambaran hasil perhitungan korelasi antara variabel talent management dengan kinerja pegawai adalah 0,518. Berarti terdapat hubungan antara talent management terhadap kinerja pegawai. Berdasarkan tabel uji signifikansi, variabel talent management terhadap kinerja pegawai memiliki nilai t hitung 4,918 yang lebih besar dari t tabel yakni 1,998. Nilai signifikansi juga menunjukkan angka 0,000 yang lebih kecil dari nilai probabilitas 0,05 . Ini berarti terdapat pengaruh yang signifikan antara talent management dengan kinerja pegawai. Maka kesimpulan yang dapat diambil adalah terdapat hubungan signifikan antara talent management terhadap kinerja pegawai pada kategori "cukup kuat". Besarnya koefisien determinasi variabel talent management terhadap kinerja pegawai adalah sebesar 0,268 atau 26,8\%. Artinya, kinerja dipengaruhi oleh variabel talent management sebesar 26,8\%. Sementara selebihnya sebesar $73,2 \%$ dipengaruhi oleh variabel lain.

Persamaan regresi $\mathrm{Y}$ atas $\mathrm{X} 1$ adalah $\hat{\mathrm{Y}}=$ $53,129+0,247 \mathrm{X}_{1}$. Dengan persamaan regresi tersebut, dapat diinterpretasikan bahwa jika variabel talent management (X1) dengan kinerja pegawai (Y) diukur dengan instrumen yang dikembangkan dalam penelitian ini, maka setiap perubahan skor variabel talent management sebesar satu satuan dapat diestimasikan skor kinerja pegawai akan berubah sebesar 0,247 satuan pada arah yang sama.

Pelaksanaan talent management dengan fokus yang kuat pada tujuan organisasi yakni memiliki Aparatur Sipil Negara berorientasi kinerja tinggi yang siap menghadapi reformasi pelayanan publik, memiliki dampak statistik yang cukup kuat dan signifikan terhadap tujuan organisasi tersebut. Hasil penelitian ini juga didukung oleh beberapa penelitian terdahulu. Di antaranya penelitian yang digagas oleh Ambia Dhinnar Febriani (2012, hal. 115) yang menyimpulkan adanya pengaruh talent management terhadap kinerja pegawai meskipun pengaruhnya hanya sebatas "cukup besar" di samping juga dipengaruhi oleh variabel-variabel lainnya yang tidak ikut diteliti. Selain itu juga penelitian yang dilakukan Pudjo Sugito dan Kamaluddin (2014, hal. 101) yang menyimpulkan adanya pengaruh positif talent management 
terhadap sustainabilitas kinerja. Di mana semakin baik implementasi talent management dilakukan, maka semakin baik pula sustainabilitas kinerja pada organisasi tersebut.

\section{Motivasi Kerja terhadap Kinerja Pegawai}

Berdasarkan hasil pengolahan dan analisis data penelitian diperoleh gambaran hasil perhitungan korelasi antara variabel motivasi kerja dengan kinerja pegawai adalah 0,665. Berarti terdapat hubungan antara motivasi kerja terhadap kinerja pegawai.

Selain itu, berdasarkan tabel uji signifikansi, variabel motivasi kerja terhadap kinerja pegawai memiliki nilai t hitung 7,243 yang lebih besar dari $\mathrm{t}$ tabel yakni 1,998. Nilai signifikansi juga menunjukkan angka 0,000 yang lebih kecil dari nilai probabilitas 0,05 . Ini berarti terdapat pengaruh yang signifikan antara motivasi kerja dengan kinerja pegawai. Maka kesimpulan yang dapat diambil adalah terdapat hubungan signifikan antara motivasi kerja terhadap kinerja pegawai pada kategori "kuat". Besarnya koefisien determinasi variabel motivasi kerja terhadap kinerja pegawai adalah sebesar 0,443 atau 44,3\%. Artinya, kinerja dipengaruhi oleh variabel motivasi kerja sebesar 44,3\%. Sementara selebihnya sebesar $55,7 \%$ dipengaruhi oleh variabel lain.

Persamaan regresi $\mathrm{Y}$ atas $\mathrm{X} 2$ adalah $\hat{\mathrm{Y}}=$ $40,118+0,557 \mathrm{X}_{2}$. Dengan persamaan regresi tersebut, dapat diinterpretasikan bahwa jika variabel motivasi kerja (X2) dengan kinerja pegawai (Y) diukur dengan instrumen yang dikembangkan dalam penelitian ini, maka setiap perubahan skor variabel motivasi kerja sebesar satu satuan dapat diestimasikan skor kinerja pegawai akan berubah sebesar 0,557 satuan pada arah yang sama.

Temuan ini sesuai dengan banyak penelitian-penelitian terdahulu yang telah dilakukan sebelumnya. Di antaranya penelitian yang dilakukan Enggar Dwi Jatmiko dkk. (2015, hal. 7) yang menyimpulkan bahwa terdapat pengaruh yang signifikan antara motivasi kerja dan kinerja karyawan. Pada penelitian tersebut disebutkan bahwa terdapat pengaruh positif dengan semakin tinggi motivasi kerja, akan diikuti pula dengan semakin tingginya kinerja pegawai. Hal ini dikarenakan motivasi kerja merupakan variabel yang paling banyak berpengaruh terhadap meningkatnya kinerja karyawan.

Penelitian lain yang juga mendukung temuan pada penelitian ini adalah oleh Tontowi Jauhari (2017, hal. 28) yang menghasilkan bahwa terdapat hubungan yang positif signifikan antara motivasi dan kinerja pegawai. Maka diperoleh kesimpulan bahwa motivasi merupakan salah satu cara untuk meningkatkan kinerja pegawai, karena dengan memberikan motivasi yang baik, maka realisasi produksi dapat tercapai sesuai dengan target organisasi.

Seiring dengan yang telah dijelaskan sebelumnya pada analisis deskriptif variabel penelitian ini, salah satu dimensi variabel motivasi penelitian yang memiliki rata-rata tertinggi adalah pada indikator kesempatan berprestasi dari dimensi prestasi/capaian. Hal ini sejalan dengan teori Mc. Clelland yang menyatakan bahwa kebutuhan akan prestasi (need for achievement $=n$ Ach.) merupakan daya penggerak yang memotivasi semangat bekerja seseorang. Karena itu kebutuhan akan prestasi akan mendorong seseorang untuk mengembangkan kreatifits dan mengarahkan semua kemampuan serta energi yang dimilikinya demi mencapai prestasi yang maksimal (Choliq, Tukiran, \& Rochman, 2014, hal. 39).

\section{Talent Management dan Motivasi Kerja terhadap Kinerja Pegawai}


Gambaran hasil perhitungan korelasi antara variabel talent management dan motivasi kerja secara bersamaan dengan kinerja pegawai adalah 0,681 . Berarti terdapat korelasi ganda yang positif dari talent management dan motivasi kerja secara bersamaan terhadap kinerja pegawai. Selain itu, berdasarkan tabel anova model regresi berganda dapat dilihat bahwa nilai $F_{\text {hitung }}$ adalah sebesar 28,114. Nilai $F_{\text {hitung }}$ ini lebih besar apabila dibandingkan dengan $\mathrm{F}_{\text {tabel(5\%;2;66) yakni sebesar }}$ 3,14. Ini berarti bahwa terdapat minimal satu variabel yang berpengaruh signifikan terhadap kinerja pegawai.

Setelah dilakukan pengujian parameter model regresi secara parsial, diketahui bahwa nilai $\mathrm{t}_{\text {hitung }}$ untuk variabel talent management (X1) adalah sebesar 1,594. Nilai tersebut lebih kecil dari $t_{\text {tabel }(0,05 ; 65)}$ yang sebesar 1,998, maka dapat disimpulkan bahwa tidak terdapat pengaruh yang signifikan antara talent management (X1) dengan kinerja pegawai (Y). Selanjutnya, nilai $t_{\text {hitung untuk }}$ variabel motivasi kerja (X2) adalah sebesar 4,870. Nilai tersebut lebih besar dari $t_{\text {tabel }(0,05 ; 65)}$ yang sebesar 1,998, maka dapat disimpulkan bahwa terdapat pengaruh yang signifikan antara motivasi kerja (X2) dengan kinerja pegawai (Y). Ini bermakna bahwa meski secara simultan talent management dan motivasi kerja berpengaruh terhadap kinerja pegawai, namun peran variabel talent management tidaklah signifikan.

Hal ini didukung pula dengan hasil analisis pada koefisien determinasi, di mana dalam tabel koefisien determinasi terlihat nilai R2 talent management dan motivasi kerja terhadap kinerja pegawai hanya sebesar 0,464 atau $46,4 \%$. Ini menunjukkan bahwa besarnya pengaruh talent management dan motivasi kerja secara bersamaan terhadap kinerja pegawai adalah sebesar 46,4\%.
Yang berarti sisanya sebesar 53,6\% dipengaruhi oleh faktor atau variabel lain.

Beberapa faktor lain yang memungkinkan untuk mempengaruhi kinerja pegawai di antaranya kepemimpinan, pengetahuan, keahlian, sikap, dan juga lingkungan. Sesuai dengan pendapat Blanchard dan Thacker (2013, hal. 60), kinerja (P) dipengaruhi oleh interaksi dari tiga faktor di antaranya motivasi (M), KSA (pengetahuan, keahlian, dan sikap), serta lingkungan (E). Baik motivasi maupun KSA adalah bagian dari ingatan dan sistem pemikiran manusia (contohnya struktur kognitif). Sementara lingkungan mengacu kepada hambatan maupun dukungan lingkungan sekitar dimana kinerja tersebut dihasilkan.

Menurut Josephine dan Harjanti (2017), lingkungan kerja merupakan kumpulan dari faktor yang bersifat fisik (orang-orang atau peralatan) maupun non fisik (situasi) dimana keduanya mempengaruhi cara pegawai bekerja. Beberapa penelitian terdahulu pun telah menunjukkan bahwa lingkungan kerja adalah salah satu variabel yang mempengaruhi kinerja pegawai, khususnya pegawai negeri sipil. Salah satu penelitian terdahulu yang mendukung hal tersebut adalah yang dilakukan Tjahyanti (2017, hal. 80) di mana hasil penelitian membuktikan bahwa lingkungan kerja berpengaruh secara signifikan terhadap kinerja pegawai negeri sipil. Hal ini menunjukkan bahwa semakin nyaman lingkungan kerja di dalam suatu instansi, maka kinerja pegawai akan semakin baik karena adanya lingkungan yang mendukung pekerjaan pegawai tersebut.

Hasil penelitian yang menunjukkan bahwa talent management berpengaruh tidak signifikan secara parsial terhadap kinerja pegawai ini tidak mendukung teori yang diutarakan Hersey, Blanchard dan Johnson (Wibowo, 2016, hal. 100) bahwa talent adalah merupakan bagian dari ability 
yang merupakan salah satu faktor yang mempengaruhi kinerja pegawai. Kendati demikian, hasil temuan ini mendukung penelitian sebelumnya yang dilakukan oleh Ridha Choirun Nisa dkk (2016, hal. 146) yang menyimpulkan bahwa manajemen talenta berpengaruh tidak signifikan secara parsial terhadap kinerja karyawan.

Hal ini dapat disebabkan oleh beberapa faktor salah satunya yaitu talent management memiliki beberapa hambatan dalam pelaksanaannya. Antara lain berkaitan dengan komitmen manajemen, konsistensi penerapan, serta pengembangan pegawai yang acapkali belum sesuai dengan sistem diterapkan oleh organisasi. Selain itu, hal ini juga dapat dipengaruhi oleh halhal yang berkaitan dengan karakteristik responden. Seperti contohnya pembatasan jenis kelamin di mana Aparatur Sipil Negara wanita di lingkungan lembaga pemerintah masih cenderung dinilai lebih mengutamakan kepentingan keluarga dibanding karier. Selain beberapa bidang yang masih didominasi oleh pria.

Apabila diamati dari hasil analisis deskriptif variabel, dimensi talent management yang memiliki nilai rata-rata terendah adalah merekrut dan menyeleksi. Meskipun proses perekrutan dan penyeleksian di Direktorat PGTK PAUD dan Dikmas khususnya dan Kementerian Pendidikan dan Kebudayaan umumnya telah dilaksanakan dengan baik berdasarkan kriteria manajemen sumber daya manusia yang benar, namun proses penempatan pegawai pun tetap masih harus diperhatikan. Di mana lembaga pemerintah saat ini masih ada yang melakukan penempatan pegawai yang tidak sesuai dengan kebutuhan organisasi, atau pun melakukan mutasi pegawai yang juga tidak sesuai dengan kebutuhan dan keadaan organisasi dalam jangka panjang.
Selain itu, dimensi mengembangkan bisa juga menjadi salah satu penanda tidak signifikannya pengaruh talent management terhadap kinerja pada Direktorat PGTK PAUD dan Dikmas Kemdikbud ini. Sebagai salah satu dimensi dengan nilai rata-rata deskriptif terendah kedua setelah merekrut dan menyeleksi, proses mengembangkan pegawai haruslah diikuti dengan komitmen bahwa setelah dilakukan pengembangan terhadap pegawai, tindak lanjutnya haruslah jelas.

Menurut Pella dan Inayati (2011, hal. 117119), ada lima tahapan program talent management yaitu: 1) Menetapkan kriteria talenta (talent criteria), 2) Menyeleksi kelompok pusat pengembangan talent (talent pool selection), 3) Membuat program percepatan pengembangan talenta (talent acceleration development program), 4) Menugaskan posisi kunci (key position assignment), dan 5) Mengevaluasi kemajuan program (monitoring program). Berdasarkan teori tersebut, seharusnya tindak lanjut pengembangan terhadap pegawai adalah menugaskan posisi kunci (key position assginment) dan mengevaluasi kemajuan program (monitoring program). Sementara yang terjadi saat ini, pengembangan pegawai pada Direktorat PGTK PAUD dan Dikmas Kemdikbud khususnya masih berdasarkan ketersediaan pegawai ketika program pengembangan dilaksanakan, atau dalam upaya memenuhi kuota calon peserta program pengembangan. Sehingga ketika dibutuhkan calon pegawai untuk menempatkan sebuah posisi kunci, para pengambil keputusan akan mencari alternatif lain untuk dicalonkan. Pada akhirnya, keputusan untuk menempatkan pegawai pada posisi kunci adalah kembali lagi kepada kebijakan dari pimpinan, bukan berdasarkan persediaan kandidat yang siap pada talent pool. 
Persamaan regresi atas kinerja pegawai (Y) yang dibentuk dari talent management (X1) dan motivasi kerja (X2) secara bersama-sama adalah $\hat{Y}=36,494+0,087 X_{1}+0,465 X_{2}$. Dengan persamaan regresi tersebut, dapat diinterpretasikan bahwa jika variabel talent management (X1) motivasi kerja (X2) dengan kinerja pegawai (Y) diukur secara bersamaan dengan instrumen yang dikembangkan dalam penelitian ini, maka setiap perubahan skor variabel talent management dan motivasi kerja sebesar satu satuan dapat diestimasikan skor kinerja pegawai akan berubah sebesar 0,087 satuan X1 dan 0,465 satuan X2 pada arah yang sama. Apabila dilihat dari besarnya koefisien korelasi, koefisien korelasi talent management dan motivasi kerja secara bersamaan dengan kinerja pegawai adalah sebesar 0,681. Sehingga dapat disimpulkan bahwa talent management dan motivasi kerja secara bersamaan memiliki hubungan dengan kinerja pegawai ke arah positif yang "kuat".

\section{SIMPULAN DAN REKOMENDASI}

Temuan dalam penelitian ini dapat membantu pihak terkait untuk lebih jelas dalam mengidentifikasi faktor-faktor yang sesungguhnya mempengaruhi kinerja pegawai di lingkungan Direktorat PGTK PAUD dan Dikmas Kemdikbud. Dengan harapan bahwa pada kesempatan selanjutnya, organisasi dapat meningkatkan kinerja pegawainya sehingga tujuan organisasi dapat tercapai.

Saran pertama yang dapat disampaikan kepada para pengambil kebijakan di lingkungan Direktorat PGTK PAUD dan Dikmas Kemdikbud adalah, dalam penerapannya sistem talent management sebaiknya harus komit, konsisten, dan sesuai dengan sistem yang diterapkan oleh organisasi itu sendiri. Seperti contohnya proses penempatan pegawai baru setelah melewati proses rekrutmen dan seleksi harus sesuai dengan pemetaan kebutuhan sumber daya manusia yang sudah dilakukan organisasi sebelumnya. Begitu juga dengan proses mutasi pegawai yang harus disesuaikan dengan keadaan organisasi, baik dalam jangka pendek maupun panjang.

Selain itu, proses pengembangan pegawai haruslah diikuti dengan komitmen tindak lanjut yang jelas. Pegawai segera diberi tanggung jawab untuk menempati suatu posisi kunci (key position assginment), lengkap dengan evaluasi dari kemajuan program penempatan tersebut. Sehingga setiap posisi atau jabatan terutama key position, tidak akan pernah mengalami kekosongan dalam jangka waktu yang terlalu signifikan dan tujuan organisasi pun dapat tercapai dengan baik dan secara maksimal. Fungsi dari talent pool harus benar-benar dimanfaatkan dengan baik sehingga persaingan sehat dalam organisasi dapat terwujud guna memotivasi pegawai untuk meningkatkan kinerja menjadi lebih baik lagi.

Dari segi motivasi kerja, masukan yang dapat dipertimbangkan adalah dengan memberikan tambahan rangsangan eksternal berupa reward, kompensasi, ataupun tambahan penghasilan kepada pegawai Direktorat PGTK PAUD dan Dikmas Kemdikbud. Karena pada dasarnya, penghasilan yang cukup dan seimbang dengan beban pekerjaan akan menghindari pegawai dari pikiran dan kesempatan untuk mencari tambahan penghasilan yang tidak sesuai aturan seperti contohnya dari praktik korupsi.

Saran secara umum yang dapat diberikan pada organisasi serupa adalah, agar organisasi lebih konsisten dan tegas dalam menerapkan 
reward and punishment terhadap pegawai. Selain itu, mengidentifikasi kepentingan pegawai dalam bekerja pada organisasi juga sangat penting, agar organisasi dapat lebih mengenal pegawai dan mengetahui faktor-faktor apa saja yang sebenarnya lebih dapat memotivasi pegawai untuk memberikan kinerja yang maksimal.

Untuk pegawai Direktorat PGTK PAUD dan Dikmas Kemdikbud, disarankan agar sebaiknya lebih sensitif dan peduli dengan lingkungan pekerjaan. Hal ini dapat dilakukan dengan menjalin hubungan sosial yang baik antar rekan kerja dan kepada organisasi. Perkuat motivasi intrinsik dan kesadaran diri sendiri, selain menanamkan rasa memiliki dan tanggung jawab terhadap organisasi guna menjadi pendorong untuk bekerja sepenuh hati dan secara maksimal.

$$
\text { Pada penelitian selanjutnya, }
$$

direkomendasikan untuk menghimpun responden dengan jumlah yang lebih banyak dan juga objek yang berbeda. Sampel diharapkan agar lebih banyak lagi dengan tujuan untuk memberikan hasil yang lebih akurat, dengan metode analisis data yang berbeda pula. Variabel pada penelitian kali ini hanya tiga yaitu talent management, motivasi kerja, dan kinerja pegawai. Sehingga pada penelitian selanjutnya diharapkan sebaiknya untuk menambah variabel penelitian agar dapat mengetahui faktor lain yang mampu mempengaruhi kinerja. Hal ini dikarenakan variabel talent management dan motivasi kerja hanya dapat menjelaskan variabel kinerja pegawai sebesar $46,4 \%$ saja, sehingga sebanyak 53,6\% faktor lain yang belum diketahui dalam penelitian ini masih banyak yang lebih mempengaruhi kinerja pegawai.

Penelitian terdahulu terkait variabel talent management dan kinerja yang pada umumnya menunjukkan bahwa talent management berpengaruh terhadap kinerja dilakukan pada organisasi swasta ataupun Badan Usaha Milik Negara (BUMN) yang berorientasi kepada profit. Organisasi pemerintah pada umumnya bertujuan untuk memberikan pelayanan untuk semua lapisan masyarakat/publik. Sedangkan organisasi swasta bertujuan untuk memperoleh keuntungan/profit sebesar-besarnya dan untuk memberikan layanan kepada orang-orang tertentu (terbatas). Sehubungan dengan perbedaan karakteristik tersebut, maka disarankan juga bagi peneliti selanjutnya untuk melakukan penelitian komparatif guna mengetahui sejauh mana talent management efektif diterapkan pada kedua jenis organisasi tersebut.

\section{DAFTAR PUSTAKA}

Adriyanto, M. (2014). Tips and Tricks on Getting the Right Talents, Strategi dan Teknik Mengelola Rekrutmen \& Seleksi untuk Mendapatkan Karyawan yang Tepat. Jakarta: PT Gramedia Pustaka Utama.

Astuti, D. P. (2014). Pengaruh Kompensasi terhadap Retensi Karyawan melalui Kepuasan Kerja dan Komitmen Afektif pada Beberapa Rumah Sakit di DKI Jakarta. Jurnal Manajemen dan Pemasaran Jasa, 7 (1), pp. 199-217.

Bintoro, \& Daryanto. (2017). Manajemen Penilaian Kinerja Karyawan. Yogyakarta: Penerbit Gava Media.

Blanchard, P. N., \& Thacker, J. W. (2013). Effective Training: Systems, Strategies, and Practices. Upper Saddle River, NJ: Pearson Prentice Hall.

Cappelli, P. (2009). Talent on Demand, Metode Baru Mendapatkan SDM Bertalenta Tepat Jumlah, Tepat Kualifikasi, dan Tepat Waktu (versi bahasa Indonesia). Jakarta: Penerbit PPM.

Choliq, N., Tukiran, \& Rochman, S. (2014). Pengaruh Motivasi Berprestasi, Iklim Sekolah, dan Kepuasan Kerja terhadap Kinerja Guru SMP di Komwil 02 Kabupaten Tegal. Sainteks, XI (1), pp. 3542.

Eriany, P., Hernawati, L., \& Goeritno, H. (2014). Studi Deskriptif Mengenai Faktor-Faktor yang Mempengaruhi Motivasi Mengikuti 
Kegiatan Bimbingan Belajar pada Siswa SMP di Semarang. Psikodimensia, 13 (1), pp. 115-130.

Febriani, A. D. (2012). Pengaruh Talent Management terhadap Kinerja Pegawai pada Kantor Pusat PT. Bank X. Depok: Universitas Indonesia.

Hayati, D. I. (2014). Perencanaan Sumber Daya Manusia Aparatur: Studi Deskriptif tentang Sistem Perencanaan SDM Pegawai Negeri Sipil di Kabupaten Kediri. Kebijakan dan Manajemen Publik 2 (1), pp. 1-9.

Jannah, N. W., \& Endratno, H. (2017). Pengaruh Motivasi Intrinsik, Motivasi Ekstrinsik, Lingkungan Kerja dan Budaya Organisasi terhadap Kinerja Karyawan Rumah Sakit Islam Banjarnegara. Jurnal Manajemen dan Bisnis MEDIA EKONOMI, XVII (1), pp. 42-54.

Jatmiko, E. D., Swasto, B., \& Eko, G (2015). Pengaruh Motivasi Kerja dan Komitmen Organisasional terhadap Kinerja Karyawan (Studi pada Karyawan Kompartemen Pabrik II PT. Petrokimia Gresik). Jurnal Administrasi Bisnis (JAB), 21 (1), pp. 1-8.

Jauhari, T. (2017). Pengaruh Motivasi Kerja terhadap Kinerja Karyawan pada Perusahaan Susu Aneka Rasa Mommy Cow Tulungagung. Jurnal Penelitian Manajemen Terapan (PENATARAN), 2 (1), pp. 18-29

Josephine, A., \& Harjanti, D. (2017). Pengaruh Lingkungan Kerja terhadap Kinerja Karyawan pada Bagian Produksi Melalui Motivasi Kerja sebagai Variabel Intervening pada PT. Trio Corporate Plastic (Tricopla). AGORA, 5 (3).

Khoerudin. (2017). External Coordination of Traffic and Road Transportation Agency about Implementation of One Way Direction System. Jurnal Governansi, 3 (2), pp. 63-70.

Mangkunegara, A. P. (2016). Manajemen Sumber Daya Manusia Perusahaan. Bandung: PT Remaja Rosdakarya.

Nawawi, H. H. (1997). Manajemen Sumber Daya Manusia, Untuk Bisnis yang Kompetitif. Yogyakarta: Gajahmada University Press.

Nisa, R. C., Astuti, E. S., \& Prasetya, A. (2016). Pengaruh Manajemen Talenta dan Manajemen Pengetahuan terhadap Kinerja Karyawan (Studi pada Karyawan PT. PLN Persero Distribusi Jawa Timur, Surabaya). Jurnal Administrasi Bisnis (JAB), 39 (2), pp. 141-148.
Pella, D. A., \& Inayati, A. (2011). Talent Management. Jakarta: PT Gramedia Pustaka Utama.

Rahmawati, I. (2015). Pengaruh Iklim Sekolah dan Motivasi Kerja Guru terhadap Kinerja Mengajar Guru Sekolah Menengah Kejuruan di Kota Bandung. Bandung: Universitas Pendidikan Indonesia.

Sayekti, W. D., Sule, E. T., Kusman, M., \& Hilmiana. (2011). Kompetensi, Kepuasan Kerja, Komitmen Organisasional, Motivasi dan Kinerja, Riset Manajemen Sumber Daya Manusia pada Program Pemberdayaan Masyarakat. Bandung: Unpad Press.

Siagian, S. P. (2009). Kiat Meningkatkan Produktivitas Kerja. Jakarta: Rineka Cipta.

Sugito, P., \& Kamaluddin. (2014). Sustainabilitas Kinerja Finansial: Studi dalam Perspektif Knowledge Management, Talent Development, dan Modal Sosial. Jurnal Keuangan dan Perbankan, 18 (1), pp. 95104.

Sugiyono. (2016). Metode Penelitian Administrasi dilengkapi dengan Metode $R \& D$. Bandung: Alfabeta.

Tjahyanti, A. S. (2017). Pengaruh Pelatihan, Pengalaman Kerja dan Lingkungan Kerja terhadap Kinerja Pegawai Negeri Sipil. Jurnal Bisnis dan Akuntansi, 19 (1a), 7681.

Wibowo. (2016). Manajemen Kinerja (Edisi Kelima). Jakarta: PT RajaGrafindo Persada. 